\title{
Revisiting the Impact of Mobile Banking in Financial Inclusion Among the Developing Countries
}

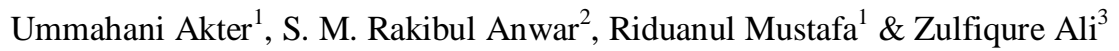 \\ ${ }^{1}$ Department of Business Administration, Bangladesh Army International University of Science and Technology, \\ Cumilla, Bangladesh \\ ${ }^{2}$ Department of Business and Technology Management, Islamic University of Technology, Gazipur, Bangladesh \\ ${ }^{3}$ Bangladesh Bank, Central Bank of Bangladesh, Bangladesh \\ Correspondence: S.M. Rakibul Anwar, Department of Business and Technology Management, Islamic University of \\ Technology, Gazipur, Bangladesh.
}

Received: August 30, 2020

Accepted: November 2, 2020

Online Published: January 11, 2021

doi:10.5430/ijfr.v12n2p62

URL: https://doi.org/10.5430/ijfr.v12n2p62

\begin{abstract}
Financial inclusion ensures financial products and services at reasonable rates for individuals and aims to introduce unbanked people into banking and financial services. The study aims to explore the effect that mobile banking facilities have on financial inclusion in 17 developing countries. From 2011 to 2017, this study took data from the three dimensions of financial inclusion called "Penetration," "Access," and "Uses". This paper took the Sarma model of Index of Financial Inclusion (IFI) to measure financial inclusion. This paper incorporates mobile money accounts as a "penetration" variable and Mobile banking outlet as an "Access" variable with existing model variables to quantify the effect of mobile banking. This research finds that mobile banking positively impacts the selected countries, though the degree of the changes is not symmetric. African regional countries have improved their financial inclusion after introducing mobile banking much better compared to other regions. This study is limited to examining mobile banking effects on selected emerging countries only. Future research may be devoted to developing more innovative strategies and tools to reach out to unbanked people, including people who face disparities in mobile phone ownership and bandwidth allocation.
\end{abstract}

Keywords: financial inclusion, penetration, access, usages, mobile banking, index of financial inclusion, developing countries

Subject Classification Codes: G2, G21, O1, O11, O16

\section{Introduction}

Financial inclusion has become a significant concern for economists, government, and researchers as there is a connection between the degree of financial inclusion and economic growth. A sound financial system with an efficient fund flow wills fast-track economic growth (McKinnon, 1973). A country's economy develops through financial services, which help people fight poverty by encouraging business, health, and education investments. Since formal financial services are inaccessible, many people, especially poor people worldwide, do their business by cash instead of financial services, which can be a security and management concern for them. That's why financial inclusion has become a major concern nowadays (Aker, Boumnijel, McClelland, \& Tierney, 2016). Dev (2006) defines financial inclusion as an effort to provide low-income and disadvantaged groups with a banking service at a reasonable minimum cost. Emerging countries should consider financial inclusion as business opportunities and social responsibilities. Financial inclusion helps improve living standards for underprivileged farmers, enterprises, and other disadvantaged groups (Dev, 2006). Financial inclusion is not only an idea of making and ensuring financial services accessible when required but also ensuring that they are achievable with fairness and transparency at an affordable cost (Sameer, Chandrashekhar, Chakrabarty, \& Phatak Deepak, 2009; UnitedNations, 2006). The financial inclusion concept is developed on the idea of availability, usage, and accessibility of financial services (A. K. Demirguc-Kunt, Leora; Singer, Dorothe; Ansar, Saniya; Hess, Jake., 2018). Sameer et al. (2009) describes that financial inclusion is no longer an option it is now a compulsion. 
Neaime and Gaysset (2018) have conducted a study on the Middle East and North Africa and found that their well-developed banking system is not sufficient to reach the underprivileged population. Mishra and Bisht (2013) conducted research on mobile banking, where they stated financial exclusion is one of the obstacles for inclusive growth. Mobile phone penetration is now opening new doors of hope for better financial inclusion. Mobile financial service has changed the existing financial products and also in the pattern of the institutions. Expansion of banks and MFIs in inaccessible areas could be fruitful, emphasizing mobile money (Akhter and Khalily, 2017). Such mobile money services make it easy to transfer and store funds through mobile, helping people earn easily and facilitate poverty reduction (Brune, Giné, Goldberg, \& Yang, 2016).

Mobile banking can easily reach poor and low-income unbanked people with different facilities. As a consequence, mobile banking services quickly outstretch in developing countries. For this reason, this study investigates the impact of mobile banking on financial inclusion through the measurement of the Index of financial inclusion. To this end, this paper has organized as follows: Section 2 reviews theoretical ground related to financial inclusion, mobile banking, financial inclusion in developing countries; Section 3 explains the methodology for calculating the Index of financial inclusion with mobile banking, and Sections 4 and 5 cover findings, the conclusion with future research direction.

\section{Literature Review}

For the current global financial crisis of exclusion, it is very crucial to emphasize financial inclusion. For strong financial inclusion, the emphasis is necessary on four key points: private sector development, financial education, microfinance development, and public sector support. Apart from the size, financial inclusion has a positive role in income inequality reduction. Financial inclusion can be accomplished by lending to individuals without undue income and facilitating funding for small and medium-sized enterprises (Turegano \& Herrero, 2018).

Sharma (2016) shows that social banking plays a vital role in country's financial inclusion. Financial inclusion promotion is considered a policy priority (Sarma \& Pais, 2008). As the strategy for more significant economic and financial gain in developing countries emphasizes financial inclusion, so lending to SMEs can boost financial inclusion through non-performing loans reduction. Financial inclusion policy can help financial stability (Demirguc-Kunt \& Klapper, 2012). Sharma (2016) mentions that financial inclusion is positively related to economic growth and various dimensions, precisely penetration of banking, availability of banking services, and usage of services. Kim (2016) shows a more robust trend that financial inclusion cut income inequality, which has a positive impact on economic growth in high instability countries than in low instability countries. According to Garg and Agarwal (2014), it is possible to achieve equitable and inclusive growth through financial inclusion, covered by reasonable costs. For ensuring financial inclusion, few factors such as innovative products, appropriate regulatory norms, and leverages are required for out of the box service models. Neaime and Gaysset (2018) carried out a study on the Middle East and North Africa and found that their well-developed banking system is not adequate to reach the underprivileged population.

Aker et al. (2016) state that the introduction of mobile banking has opened a new dimension of cash transfers. This increased cash transfer has significantly increased diet diversity and meal intake per day, saving time. The electronic transfer can play an essential role in overcoming the logistics challenges in cash transfer with proper investment for the sector's development in developing countries. Mobile phone uses are necessary to accelerate digital finance, so that poor can be benefited from the new technology and get the excess of formal financial facilities. Financial inclusion gets promoted with this improvement of financial services and cost reduction (Evans, 2018). Rapidly increasing mobile phone uses leveraging mobile money service growth globally (Lashitew, van Tulder, \& Liasse, 2019). Mobile phones are being used to provide financial services through mobile money is a recent financial innovation that reduces unbanked poor. This service "leapfrogging" the provision of a formal baking system in developing countries(Aron, 2017). Mobile Money services create a window for low-income portions of society and unbanked people to get adaptable and affordable payment and financial services (Munyegera \& Matsumoto, 2016). The larger informal economy, which defines the developing country, can be facilitated by mobile money, adding value to equitable and balanced development (Foster \& Heeks, 2013). By reducing travel time, enhancing safety, and elaborating convenience, and highlighting information and technology (Aron, 2017), mobile money demonstrates noticeable improvement in terms of efficiency compared to traditional money transferring system (Jack \& Suri, 2014; Munyegera \& Matsumoto, 2016).

Besides, mobile money account users get capital and interest offer from the bank. Apart from this, users of the mobile banking system can link their existing bank account with their mobile bank account or open new account using mobile money account (Mas \& Radcliffe, 2011). Various functions can be done through mobile banking, such 
as utility bill payment, money transfer, fees payment, and buying products and services (Demirguc-Kunt \& Klapper, 2012). According to Rangarajan (2008) financial services can be promoted in rural areas with minimum operation cost through the use of proper technological support such as mobile money banking. Mobile based service is mobile money that ensures unbaked people to have excess in financial services with low-cost. Mishra and Bisht (2013) find it as an excellent option to accelerate financial inclusion by including remote unbanked people. The purpose of this system is to facilitate the entry of those people who have difficulties to avail formal banking facilities (Della Peruta, 2018). Moreover, the scope of financial inclusion increased by the increased usage and adaptation of mobile money in developing countries (Bongomin \& Ntayi, 2019). The main goal for mobile money banking is financial inclusion for those people who can not avail the financial services (Maurer, 2012). Mobile money usually have higher impact on low income countries through the development of mobile phone services(Roller \& Waverman, 2001; Waverman, Meschi, \& Fuss, 2005). People's saving behavior will be formalized with this mobile money banking system (Mbiti \& Weil, 2013). As per innovations such as mobile phones, usage has been used to introduce financial services; they increase household level savings (Ouma, Odongo, \& Were, 2017). According to Chinoda and Kwenda (2019), financial inclusion in 49 counties is improved by mobile money service.

Akhter and Khalily (2017) examine the usefulness of mobile financial services for Bangladesh and found that mobile financial services are beneficial. A mobile financial system incorporates excluded groups such as low-income or micro-entrepreneur, which strongly influence poverty alleviation and growth. Mobile banking has a positive role in ensuring financial inclusion. Recent research reveals that many development benefits from financial inclusion, such as mobile money, cards, and many other financial technology applications that greatly influence this regard. Benefits from financial technologies include storage and transfer of funds from distant, can cut financial risk by collecting money from distant friends or sources. It can cut the cost of the transaction. It can help accumulate savings and increase expenditure (A. K. Demirguc-Kunt, Leora; Singer, Dorothe; Ansar, Saniya; Hess, Jake., 2018). Evans (2018) shows that the mobile phone and the internet significantly influence financial inclusion; the increasing trend of internet and mobile is also increasing financial inclusion. Financial inclusion also imposes a positive impact on financial stability. Similarly, half of the world's population still lacks a formal bank account and financial services (Rizvi, Naqvi, \& Tanveer, 2017). Mobile banking can reduce the barriers to financial inclusion with a variety of services. Economies with weak financial structure and high banking costs have benefitted considerably from mobile banking.

For measuring financial inlcusion of a country, Sharma has introduced a multidimensional measure called Index of Financial Inclusion (IFI), which is in line with development indexes such as HDI, HPI, GDI, and GED. Financial inclusion of different economies can be calculated, compared, and monitored by IFI (Sarma, 2008). Cámara and Tuesta (2014) summarize that the implementation of financial inclusion depends upon three factors: uses, barrier, and access. The two-state principal component analysis has determined the weights of the dimensions. To find a comprehensive measure of financial inclusion, Sarma (2008) has proposed an Index for financial inclusion. After capturing the data from various dimensions, it expresses the result on a scale between 0 to 1 . Where to represent a complete absence of financial inclusion represents 0 , and 1 means complete financial inclusion. Following the Index proposed by Sharma 2008, a cross country analysis had done by (Sarma \& Pais, 2008). Financial inclusion can ensure the participation of financially vulnerable groups into the financial system. The paper focuses on the determinants of financial inclusion and the Index of financial inclusion (Gupte, Venkataramani, \& Gupta, 2012). Bihari (2011) also uses a multidimensional index for financial inclusion measurement. The dimensions are access, penetration, and usages.

A handful of papers discussed mobile banking and its contribution to financial inclusion, but no paper discussed how mobile banking could be brought into financial inclusion measurement. For getting financial inclusion index, previous index measurement only considers the number of bank account as a penetration dimension and number of bank branches and ATM branches as access dimensions. But, in today's world, mobile banking account provides banking penetration facility to its customer in more wide extent and mobile banking outlet provide quick access services rather traditional bank and ATM branches. That's why this study incorporates mobile banking account and outlet in calculating financial inclusion index. This index helps developing countries to know their progress in financial inclusion with considering mobile banking and its outlet.

\section{Methodology}

Various measurements are developed by researchers to measure the financial inclusion of an economy from time to time. We measured the Index of financial inclusion for developing countries using the model developed by (Sarma, 2012). Sarma follows a distinct approach to construct the Index. In the Index presented in this study, three basic 
dimensions of an inclusive financial system are considered. To know the bank penetration, in the Sarma model, a bank account with commercial bank per 1000 adults have been considered as D1 that means the dimension of penetration. Here for bank penetration, we include deposit accounts with commercial banks per 1,000 adults as D1a, loan accounts with commercial banks per 1,000 adults as D1b; and mobile money accounts: registered per 1,000 adults as D1c. For getting D1, we assign equal weight to these three variables. This measure's value will be 1 if every person of an economy owns in the minimum a deposit, a loan, or a mobile bank account.

In the Sarma index of the financial inclusion model, two separate indexes are calculated for bank branches and ATMs to know the availability of financial services as D2. A weighted average of these two indexes, using $2 / 3 \mathrm{rd}$ weight for the bank branch index and 1/3rd weight for the ATM index, is considered the Index for the availability dimension. Here for the dimension of availability, we newly considered the mobile banking outlet as a third variable named D2c. For getting D2, we assign equal weight to these three variables.

Incorporating the usage dimension in the present Index as D3, we consider two basic banking system services credit and deposit. The appropriate indicators for these would be the volume of credit and deposit to adult individuals as a proportion of Gross Domestic Product (GDP). This IFI includes a single number between 0 and 1 that captures information on banking penetration, availability of services, and usage of banking systems. In this Index, 0 denotes complete financial exclusion, and complete financial inclusion is indicated by 1 .

The dimension indexes $\mathrm{d}_{\mathrm{i}}$, as computed by the formula (1), measures the country's achievement in the $\mathrm{i}^{\text {th }}$ dimension of financial inclusion. A weight $w_{i}$ such that $0 \leq w_{i} \leq 1$ is attached to the dimension $i$, indicating the relative importance of the dimension $i$ in quantifying the inclusiveness of a financial system (Sarma, 2012).

For measuring dimension -

$$
d_{i}=w_{i} \frac{A_{i}-m_{i}}{M_{i}-m_{i}}
$$

Where, $w_{i}=$ weight attached to the dimension i, $0 \leq w_{i} \leq 1$

$\mathrm{A}_{\mathrm{i}}=$ actual value of dimension $\mathrm{i}$

$\mathrm{m}_{\mathrm{i}}=$ lower limit on the value of dimension $\mathrm{i}$, fixed by some pre-specified rule.

$\mathrm{M}_{\mathrm{i}}=$ upper limit on the value of dimension $\mathrm{i}$, fixed by some pre-specified rule.

For calculating dimensions, we consider the following upper and lower bounds to be reasonable for different dimensions

\begin{tabular}{llllllll}
\hline Dimension & D1a & D1b & D1c & D2a & D2b & D2c & D3 \\
\hline $\max$ & 7269.09 & 2888.42 & 1823.35 & 313.15 & 258.72 & 1142.96 & 825.29 \\
\hline $\min$ & 20.12 & 0.84 & 0.26 & 0.09 & 0.45 & 0.05 & 3.26 \\
\hline
\end{tabular}

* $\mathrm{D} 1 \mathrm{a}=$ the Deposit accounts with commercial banks per 1,000 adults

$\mathrm{D} 1 \mathrm{~b}=$ loan accounts with commercial banks per 1,000 adults.

$\mathrm{D} 1 \mathrm{c}=$ Mobile money accounts: registered per 1,000 adults

D1 $=$ the penetration of Financial institution the composition of a weighted total of D1a, D1b, and D1c

D2a $=$ Automated Teller Machines (ATMs) per 100,000 adults

$\mathrm{D} 2 \mathrm{~b}=$ the number of Branches of commercial banks per 100,000 adults.

D2c $=$ Mobile money agent outlets registered per 100,000 adults

D2 $=$ the Access of Financial institution the composition of a weighted total of D2a, D2b, and D2c

D3 $=$ the Usages of the financial services

Algebraically, from the Index of financial inclusion from (Sarma, 2012) 


$$
I F I_{k}=\frac{1}{2}\left[\frac{\sqrt{p^{2}{ }_{k}+a^{2}{ }_{k}+u^{2}{ }_{k}}}{\sqrt{3}}+\left(1-\frac{\sqrt{\left(1-p_{k}\right)^{2}+\left(1-a_{k}\right)^{2}+\left(1-u_{k}\right)^{2}}}{\sqrt{3}}\right)\right]
$$

\section{Findings and Analysis}

4.1 Three-Dimensional Scenarios of Financial Inclusion Among Asian Countries: Penetration, Access, and Usages

Table 1 demonstrates the Asian countries' financial inclusion in three-dimensional aspects: penetration, access, and usage. In the table column D1a, all other countries except Myanmar, Afghanistan, and Jordan are going through a continuous increase in the number of bank account. Bangladesh is at the top with a higher number of .0345. From 2016 to 2017, Myanmar faced a decline from 0.0107 to .0094, and Jordan and Afghanistan observed a slight decrease from 0.0236 to .0235 and from .0078 to .0075 respectively in the number of bank account. The second column D1b in table-2 shows that Pakistan has gone through an increase after 2015 from .0029 to .0032 . Jordan's loan accounts are getting popular day by day as from 2014 to 2017 , Jordan has witnessed a rise from .0177 to .0234 . On the other hand, Bangladesh faced a negligible increase.

Table 1. Comparison of banking penetration, access, usages among selected Asian countries

\begin{tabular}{|c|c|c|c|c|c|c|c|c|c|c|}
\hline \multicolumn{2}{|c|}{ Selected Country } & \multicolumn{4}{|c|}{ Banking penetration } & \multicolumn{4}{|c|}{ Banking Access } & \multirow{2}{*}{$\begin{array}{l}\text { Usage } \\
\text { D3 }\end{array}$} \\
\hline Economy & Year & D1a & D1b & D1c & D1 & D2a & D2b & D2c & D2 & \\
\hline \multirow[t]{6}{*}{ Afghanistan } & 2012 & 0.0070 & 0.0000 & 0.0150 & 0.0220 & 0.0000 & 0.0000 & 0.0070 & 0.0080 & 0.0230 \\
\hline & 2013 & 0.0050 & 0.0000 & 0.0150 & 0.0200 & 0.0000 & 0.0010 & 0.0090 & 0.0100 & 0.0230 \\
\hline & 2014 & 0.0070 & 0.0000 & 0.0140 & 0.0220 & 0.0000 & 0.0010 & 0.0130 & 0.0130 & 0.0240 \\
\hline & 2015 & 0.0080 & 0.0000 & 0.0020 & 0.0100 & 0.0010 & 0.0000 & 0.0170 & 0.0180 & 0.0240 \\
\hline & 2016 & 0.0080 & 0.0000 & 0.0040 & 0.0120 & 0.0010 & 0.0000 & 0.0150 & 0.0170 & 0.0230 \\
\hline & 2017 & 0.0080 & 0.0000 & 0.0050 & 0.0130 & 0.0010 & 0.0000 & 0.0210 & 0.0220 & 0.0250 \\
\hline \multirow[t]{7}{*}{ Bangladesh } & 2011 & 0.0230 & 0.0100 & 0.0000 & 0.0340 & 0.0040 & 0.0020 & 0.0110 & 0.0170 & 0.1070 \\
\hline & 2012 & 0.0250 & 0.0100 & 0.0020 & 0.0370 & 0.0040 & 0.0020 & 0.0510 & 0.0570 & 0.1090 \\
\hline & 2013 & 0.0270 & 0.0110 & 0.0210 & 0.0590 & 0.0060 & 0.0020 & 0.3900 & 0.3980 & 0.1060 \\
\hline & 2014 & 0.0280 & 0.0100 & 0.0400 & 0.0770 & 0.0070 & 0.0020 & 1.0200 & 1.0290 & 0.1090 \\
\hline & 2015 & 0.0300 & 0.0100 & 0.0550 & 0.0950 & 0.0080 & 0.0020 & 1.0550 & 1.0660 & 0.1090 \\
\hline & 2016 & 0.0320 & 0.0100 & 0.0650 & 0.1070 & 0.0090 & 0.0020 & 1.2820 & 1.2940 & 0.1090 \\
\hline & 2017 & 0.0350 & 0.0100 & 0.0910 & 0.1360 & 0.0100 & 0.0020 & 1.3950 & 1.4070 & 0.1080 \\
\hline \multirow[t]{7}{*}{ Cambodia } & 2011 & 0.0050 & 0.0030 & 0.0030 & 0.0120 & 0.0070 & 0.0010 & 0.0180 & 0.0260 & 0.0810 \\
\hline & 2012 & 0.0060 & 0.0040 & 0.0040 & 0.0140 & 0.0090 & 0.0010 & 0.0170 & 0.0270 & 0.0990 \\
\hline & 2013 & 0.0070 & 0.0040 & 0.0050 & 0.0160 & 0.0100 & 0.0010 & 0.0190 & 0.0310 & 0.1030 \\
\hline & 2014 & 0.0090 & 0.0050 & 0.0060 & 0.0200 & 0.0130 & 0.0020 & 0.0450 & 0.0600 & 0.1260 \\
\hline & 2015 & 0.0110 & 0.0050 & 0.0080 & 0.0240 & 0.0170 & 0.0020 & 0.0710 & 0.0900 & 0.1420 \\
\hline & 2016 & 0.0120 & 0.0070 & 0.0110 & 0.0300 & 0.0180 & 0.0020 & 0.3530 & 0.3730 & 0.1610 \\
\hline & 2017 & 0.0140 & 0.0070 & 0.0390 & 0.0600 & 0.0210 & 0.0020 & 0.4390 & 0.4620 & 0.1780 \\
\hline \multirow[t]{4}{*}{ Jordan } & 2014 & 0.0230 & 0.0180 & 0.0010 & 0.0420 & 0.0320 & 0.0040 & 0.0000 & 0.0370 & 0.2320 \\
\hline & 2015 & 0.0230 & 0.0180 & 0.0020 & 0.0430 & 0.0310 & 0.0040 & 0.0020 & 0.0370 & 0.2410 \\
\hline & 2016 & 0.0240 & 0.0210 & 0.0020 & 0.0460 & 0.0340 & 0.0040 & 0.0040 & 0.0430 & 0.2430 \\
\hline & 2017 & 0.0240 & 0.0230 & 0.0050 & 0.0520 & 0.0360 & 0.0040 & 0.0270 & 0.0660 & 0.2430 \\
\hline Myanmar & 2014 & 0.0070 & 0.0000 & 0.0000 & 0.0070 & 0.0020 & 0.0010 & 0.0010 & 0.0030 & 0.0390 \\
\hline
\end{tabular}




\begin{tabular}{lllllllllll}
\hline & 2015 & 0.0090 & 0.0000 & 0.0000 & 0.0100 & 0.0020 & 0.0010 & 0.0050 & 0.0070 & 0.0450 \\
\cline { 2 - 9 } & 2016 & 0.0110 & 0.0000 & 0.0010 & 0.0120 & 0.0030 & 0.0010 & 0.0110 & 0.0150 & 0.0550 \\
\hline \multirow{2}{*}{2017} & 0.0090 & 0.0000 & 0.0070 & 0.0170 & 0.0050 & 0.0010 & 0.0890 & 0.0960 & 0.0560 \\
\cline { 2 - 9 } & 2011 & 0.0120 & 0.0030 & 0.0010 & 0.0170 & 0.0060 & 0.0020 & 0.0420 & 0.0500 & 0.0510 \\
\hline 2012 & 0.0130 & 0.0030 & 0.0030 & 0.0200 & 0.0060 & 0.0020 & 0.0760 & 0.0850 & 0.0530 \\
\hline 2013 & 0.0140 & 0.0030 & 0.0050 & 0.0220 & 0.0080 & 0.0030 & 0.2230 & 0.2330 & 0.0530 \\
\hline 2014 & 0.0150 & 0.0030 & 0.0080 & 0.0260 & 0.0090 & 0.0030 & 0.3550 & 0.3670 & 0.0530 \\
\hline 2015 & 0.0160 & 0.0030 & 0.0230 & 0.0420 & 0.0110 & 0.0030 & 0.5130 & 0.5270 & 0.0520 \\
\hline & 2016 & 0.0170 & 0.0030 & 0.0290 & 0.0490 & 0.0120 & 0.0030 & 0.5980 & 0.6130 & 0.0560 \\
\hline
\end{tabular}

D1c from the table represents that Bangladesh faced a massive increase from .0002 to .0910 from 2011 to 2017. The number of mobile operators is increasing day by day. But the rise is more than 200 times between 2012 to 2017. Bangladesh reached from D1c 0.001 in 2012 to 0.091 in 2017, Pakistan also faced the same increase. Mobile accounts got popularity also in Cambodia with an escalation after 2015. In 2017.0050 and .0074, respectively, Afghanistan and Mayanmar noticed a sharp rise compared to 2016. D1 is the composition of a weighted total of D1a, D1b, and D1c. Among the observed Asian nations, Bangladesh is comparatively in a better stand (0.0952) in penetration. After 2014, the Asian region as a whole spots an increase. With a considerable improvement after 2014, Pakistan is in a close position (0.0737) to Bangladesh. Cambodia with (0.0595) went past Jordan (0.0523) in 2017. Myanmar's penetration improved slightly from 2015 to 2017, but Afghanistan's decreased.

D2a from Table-2 presents that with more than 30 ATMs, Jordan has the most significant number of ATMs (.0355) among Asian countries. The number of ATM has increased since 2012 in countries such as Cambodia, Bangladesh, and Pakistan, except Afghanistan. Table-2 column D2b shows that even though the number of bank branches per capita in Jordan declined in 2016, it still has the highest value (.0042) among Asian countries in 2017. But both Bangladesh and Pakistan present a similar pattern with a slight increase around the years. In Afghanistan, the ATM facility is not as remarkable as in other countries in Asia. D2c column shows that the number of mobile money agent outlets was not high in the beginning. But the number increased after 2012 for Bangladesh from .0505 to 1.3949. Pakistan also witnessed increased mobile money agent outlets but, Afghanistan faced a slight increase from .0074 in 2012 to .0209 in 2017. All these increases indicate that Mobile money accounts are gaining popularity.

In Table-1, the D2 column presents that after 2013, Bangladesh witnessed drastic changes in access from .0173 in 2012 to 1.4071 in 2017. From 2013, Pakistan's D2 also improved continuously (from .0503 to .6763). And after 2015, Cambodia Access decreased from .0897 to .4618. The D2 of Afghanistan and Myanmar even improved but low. The D3 Consists of Outstanding deposits with commercial banks (\% of GDP) and outstanding loans with commercial banks (\% of GDP). Jordan is the relatively better-performing country that accounts for maximum uses ( 0.24$)$ than other Asian countries. Cambodia is displaying a consistent increase from .0812 to .1782 . Bangladesh shows a slight increase and decreases among the years between 2011 and 2017 in terms of the usage of banking services. Myanmar improves its usages almost as similar as Pakistan does.

\subsection{Three-Dimensional Scenarios of Financial Inclusion Among African Countries: Penetration, Access, and Usages}

Among the selected countries from Africa, Seychelles is clearly in a better position in terms of D1a. There are almost .098 deposit accounts registered against 1000 adults in 2017. Other African countries are in a relatively stagnant situation in comparison with Seychelles. After 2016 a mere change has been observed for most of these nations.

Table 2. Comparison of banking penetration, access, usages among selected African countries

\begin{tabular}{lllllllllll}
\hline \multicolumn{2}{l}{ Selected Country } & \multicolumn{3}{l}{ Banking penetration } & \multicolumn{3}{c}{ Banking Access } & \multicolumn{2}{c}{ Usage } \\
\hline Economy & Year & D1a & D1b & D1c & D1 & D2a & D2b & D2c & D2 & D3 \\
\hline Guinea & 2015 & 0.0028 & 0.0020 & 0.0259 & 0.0307 & 0.0021 & 0.0006 & 0.1268 & 0.1295 & 0.0285 \\
\cline { 2 - 11 } & 2016 & 0.0025 & 0.0017 & 0.0429 & 0.0471 & 0.0023 & 0.0006 & 0.4174 & 0.4202 & 0.0272 \\
\hline
\end{tabular}




\begin{tabular}{|c|c|c|c|c|c|c|c|c|c|c|}
\hline & 2017 & 0.0029 & 0.0015 & 0.0579 & 0.0623 & 0.0023 & 0.0006 & 0.8433 & 0.8462 & 0.0214 \\
\hline \multirow[t]{7}{*}{ Madagascar } & 2011 & 0.0016 & 0.0023 & 0.0133 & 0.0172 & 0.0014 & 0.0003 & 0.0328 & 0.0345 & 0.0294 \\
\hline & 2012 & 0.0018 & 0.0024 & 0.0190 & 0.0232 & 0.0016 & 0.0003 & 0.0530 & 0.0550 & 0.0298 \\
\hline & 2013 & 0.0023 & 0.0027 & 0.0235 & 0.0285 & 0.0017 & 0.0003 & 0.0717 & 0.0738 & 0.0292 \\
\hline & 2014 & 0.0027 & 0.0038 & 0.0287 & 0.0351 & 0.0021 & 0.0004 & 0.1145 & 0.1170 & 0.0302 \\
\hline & 2015 & 0.0034 & 0.0035 & 0.0322 & 0.0392 & 0.0024 & 0.0004 & 0.1601 & 0.1629 & 0.0337 \\
\hline & 2016 & 0.0036 & 0.0032 & 0.0506 & 0.0574 & 0.0027 & 0.0005 & 0.1924 & 0.1956 & 0.0352 \\
\hline & 2017 & 0.0041 & 0.0048 & 0.0754 & 0.0842 & 0.0030 & 0.0005 & 0.2678 & 0.2714 & 0.0367 \\
\hline \multirow[t]{3}{*}{ Seychelles } & 2015 & 0.0925 & 0.0270 & 0.0038 & 0.1232 & 0.0841 & 0.0154 & 0.1573 & 0.2568 & 0.1080 \\
\hline & 2016 & 0.0946 & 0.0296 & 0.0048 & 0.1289 & 0.0920 & 0.0153 & 0.2295 & 0.3368 & 0.1154 \\
\hline & 2017 & 0.0984 & 0.0372 & 0.0051 & 0.1407 & 0.1015 & 0.0151 & 0.2133 & 0.3299 & 0.1166 \\
\hline \multirow[t]{7}{*}{ Rwanda } & 2011 & 0.0124 & 0.0009 & 0.0190 & 0.0324 & 0.0029 & 0.0014 & 0.0473 & 0.0517 & 0.0297 \\
\hline & 2012 & 0.0144 & 0.0011 & 0.0417 & 0.0572 & 0.0054 & 0.0015 & 0.1029 & 0.1098 & 0.0323 \\
\hline & 2013 & 0.0130 & 0.0016 & 0.0714 & 0.0861 & 0.0061 & 0.0016 & 0.2812 & 0.2889 & 0.0338 \\
\hline & 2014 & 0.0102 & 0.0038 & 0.1771 & 0.1912 & 0.0065 & 0.0015 & 0.8969 & 0.9050 & 0.0370 \\
\hline & 2015 & 0.0082 & 0.0040 & 0.2034 & 0.2156 & 0.0065 & 0.0016 & 1.2297 & 1.2379 & 0.0413 \\
\hline & 2016 & 0.0099 & 0.0033 & 0.2507 & 0.2639 & 0.0067 & 0.0016 & 1.7679 & 1.7763 & 0.0401 \\
\hline & 2017 & 0.0099 & 0.0022 & 0.2270 & 0.2390 & 0.0066 & 0.0016 & 2.3912 & 2.3994 & 0.0396 \\
\hline \multirow[t]{5}{*}{ Uganda } & 2013 & 0.0076 & 0.0020 & 0.1352 & 0.1448 & 0.0054 & 0.0007 & 0.5820 & 0.5881 & 0.0300 \\
\hline & 2014 & 0.0082 & 0.0024 & 0.1718 & 0.1823 & 0.0049 & 0.0007 & 0.8264 & 0.8320 & 0.0318 \\
\hline & 2015 & 0.0094 & 0.0042 & 0.1855 & 0.1991 & 0.0051 & 0.0007 & 1.1018 & 1.1076 & 0.0332 \\
\hline & 2016 & 0.0107 & 0.0038 & 0.1828 & 0.1973 & 0.0050 & 0.0007 & 1.2888 & 1.2945 & 0.0336 \\
\hline & 2017 & 0.0158 & 0.0034 & 0.1855 & 0.2048 & 0.0047 & 0.0006 & 1.4916 & 1.4968 & 0.0335 \\
\hline \multirow[t]{7}{*}{ Zambia } & 2011 & 0.0058 & 0.0022 & 0.0102 & 0.0182 & 0.0082 & 0.0010 & 0.0899 & 0.0991 & 0.0312 \\
\hline & 2012 & 0.0075 & 0.0031 & 0.0325 & 0.0430 & 0.0099 & 0.0011 & 0.1925 & 0.2034 & 0.0347 \\
\hline & 2013 & 0.0106 & 0.0042 & 0.0557 & 0.0706 & 0.0111 & 0.0011 & 0.3714 & 0.3837 & 0.0361 \\
\hline & 2014 & 0.0120 & 0.0042 & 0.1035 & 0.1197 & 0.0125 & 0.0012 & 0.3294 & 0.3431 & 0.0372 \\
\hline & 2015 & 0.0127 & 0.0037 & 0.1021 & 0.1186 & 0.0135 & 0.0012 & 0.4579 & 0.4726 & 0.0442 \\
\hline & 2016 & 0.0133 & 0.0027 & 0.1279 & 0.1439 & 0.0138 & 0.0012 & 0.4716 & 0.4866 & 0.0354 \\
\hline & 2017 & 0.0070 & 0.0027 & 0.2266 & 0.2363 & 0.0140 & 0.0012 & 0.4853 & 0.5004 & 0.0346 \\
\hline \multirow[t]{6}{*}{ Zimbabwe } & 2012 & 0.0049 & 0.0067 & 0.0175 & 0.0291 & 0.0050 & 0.0032 & 0.0783 & 0.0865 & 0.0467 \\
\hline & 2013 & 0.0066 & 0.0072 & 0.0507 & 0.0644 & 0.0049 & 0.0034 & 0.1639 & 0.1721 & 0.0432 \\
\hline & 2014 & 0.0031 & 0.0074 & 0.1228 & 0.1333 & 0.0062 & 0.0036 & 0.5945 & 0.6042 & 0.0429 \\
\hline & 2015 & 0.0030 & 0.0072 & 0.1668 & 0.1770 & 0.0073 & 0.0014 & 0.8778 & 0.8865 & 0.0426 \\
\hline & 2016 & 0.0048 & 0.0036 & 0.1723 & 0.1807 & 0.0072 & 0.0014 & 0.8969 & 0.9055 & 0.0554 \\
\hline & 2017 & 0.0171 & 0.0041 & 0.2031 & 0.2243 & 0.0069 & 0.0011 & 1.0298 & 1.0378 & 0.0779 \\
\hline
\end{tabular}

Seychelles is in a better spot than the deposit accounts with the loan accounts composed of 37 loan accounts counted against 1000 adults in 2017, which has increased from 29 in 2016 to 26 in 2015. Other African nations yet to go a long way with less than 05 loan account in 2017. In table-2, D1c column observed an increase after 2013. Zambia and Rwanda are in a relatively better position, with around 0.226 and 0.227 accounts. Mobile accounts in Zambia and 
Zimbabwe, all of them have above 0.180 mobile accounts in 2017. There is another cluster of countries below 0.10 accounts; they are Madagascar, Seychelles, and Guinea. The paper tries to investigate the D1 for Africa. Countries with a score of above 0.2 and a score of below 0.1. Rwanda and Zambia are relatively better positioned than other countries, followed by Zimbabwe and Uganda. After a few ups and downs, from 2015, all the countries have faced an increase in the Index. The penetration of Guinea is least ranked compared to the penetration of the African nations.

The number of ATMs in Seychelles is the highest among the selected African countries. Although, for every country, the number of ATMs is increasing slowly. The number of bank branches per 100,000 adults experienced a decrease below 10 after 2014 for all the countries. Seychelles is relatively in a better position among the African nations. The table-3 shows that in recent years, mobile banking is gaining popularity among African nations. Later in 2014, all the African nations are almost in a similar situation in establishing mobile banking outlets, but Rwanda and Uganda, and Zimbabwe brought a massive increase by 2016. The chart depicts a reasonable Access before 2014 in African nations. Rwanda and Uganda observed a gigantic change in their access to financial services by the observed period with all the changes. Among African nations, Seychelles has better Usages 0.116. In 2017, Zimbabwe reached a relatively better situation at 0.077. All African countries witness several fluctuations except Zimbabwe, which observes remarkable improvement between 2015 and 2017.

4.3 Three-Dimensional Scenarios of Financial Inclusion Among Oceania Countries: Penetration, Access, and Usages

In the Oceania region, the study considered Samoa, Solomon Island, and Tonga for the analysis. Samoa is in a better state among the countries in terms of penetration. In Samoa, the number of bank account per 1000 adults has decreased in 2014 but continued to rise after 2014 till 2017 indicates more than 0.80 accounts. Tonga, however, has increased with a reduced account record for 2016. Solomon Island is the least performing country on the list with slightly above 0.20 accounts. The number of loan account for Oceania countries fluctuated regularly except for Solomon Island, starting to decline from 2015. Samoa and Tonga, above 0.15 accounts, are relatively in a better situation than Solomon Island, under 05 accounts. After 2015, the number of mobile bank account became popular among the Oceania countries. The number of mobile bank account in Tonga has increased from 0.100 accounts in 2015 to 0.110 accounts in 2017. The same trend followed by the other two countries such as Samoa, from about 0.71 accounts in 2016 to above 0.83 accounts in 2017 and Solomon Island, the least performing country, also get above 0.50 accounts by 2016 but suddenly decreased in 2017.

The overall penetration performance analysis interprets that in 2015 both Samoa and Tonga are relatively in the same place. But after 2015, Tonga has gone through a sharp rise apart from a decline in 2016. In 2016, with a rate of above 15 percent, Samoa offset Tonga in terms of penetration. Solomon Island has the least penetration rate, which is under 10 percent, among Oceania countries. With ATM access with over 0.50 ATMs for 100,000 adults and an increasing trend, Samoa is in a relatively better state compared to other Oceania countries. The Solomon Islands and Tonga also improved in terms of ATM access.

Table 3. Comparison of banking penetration, access, usages among selected Oceania countries

\begin{tabular}{lllllllllll}
\hline Selected Country & \multicolumn{4}{c}{ Banking penetration } & \multicolumn{3}{c}{ Banking Access } & \multicolumn{2}{c}{ Usage } \\
\hline Economy & Year & D1a & D1b & D1c & D1 & D2a & D2b & D2c & D2 & D3 \\
\hline Samoa & 2013 & 0.0714 & 0.0144 & 0.0642 & 0.1500 & 0.0450 & 0.0065 & 0.2588 & 0.3103 & 0.0964 \\
\cline { 2 - 11 } & 2014 & 0.0654 & 0.0135 & 0.0715 & 0.1504 & 0.0530 & 0.0069 & 0.0643 & 0.1242 & 0.1009 \\
\cline { 2 - 11 } & 2015 & 0.0678 & 0.0136 & 0.0733 & 0.1546 & 0.0524 & 0.0061 & 0.0240 & 0.0826 & 0.0973 \\
\cline { 2 - 11 } & 2016 & 0.0822 & 0.0151 & 0.0713 & 0.1686 & 0.0601 & 0.0065 & 0.0220 & 0.0886 & 0.0999 \\
\hline Solomon Islands & 2017 & 0.0825 & 0.0159 & 0.0834 & 0.1817 & 0.0636 & 0.0064 & 0.0218 & 0.0918 & 0.1006 \\
& 2013 & 0.0106 & 0.0041 & 0.0082 & 0.0229 & 0.0139 & 0.0009 & 0.0285 & 0.0433 & 0.0487 \\
& 2014 & 0.0199 & 0.0045 & 0.0176 & 0.0420 & 0.0139 & 0.0010 & 0.0779 & 0.0929 & 0.0508 \\
\cline { 2 - 10 } & 2015 & 0.0214 & 0.0044 & 0.0227 & 0.0485 & 0.0143 & 0.0010 & 0.0977 & 0.1130 & 0.0550
\end{tabular}




\begin{tabular}{lllllllllll}
\hline & 2016 & 0.0225 & 0.0034 & 0.0528 & 0.0787 & 0.0143 & 0.0010 & 0.1561 & 0.1714 & 0.0581 \\
\cline { 2 - 10 } & 2017 & 0.0237 & 0.0031 & 0.0472 & 0.0740 & 0.0149 & 0.0011 & 0.1309 & 0.1469 & 0.0592 \\
\hline Tonga & 2011 & 0.0259 & 0.0116 & 0.0224 & 0.0600 & 0.0348 & 0.0061 & 0.1595 & 0.2003 & 0.0771 \\
\cline { 2 - 10 } & 2012 & 0.0330 & 0.0078 & 0.0605 & 0.1012 & 0.0346 & 0.0056 & 0.1777 & 0.2179 & 0.0857 \\
\cline { 2 - 10 } & 2013 & 0.0354 & 0.0150 & 0.0232 & 0.0736 & 0.0344 & 0.0060 & 0.1515 & 0.1919 & 0.0932 \\
\hline & 2014 & 0.0409 & 0.0120 & 0.1097 & 0.1626 & 0.0323 & 0.0051 & 0.1504 & 0.1878 & 0.0976 \\
\hline & 2015 & 0.0466 & 0.0187 & 0.1006 & 0.1659 & 0.0320 & 0.0085 & 0.4009 & 0.4414 & 0.1059 \\
\hline & 2016 & 0.0353 & 0.0189 & 0.1071 & 0.1612 & 0.0410 & 0.0084 & 0.0398 & 0.0892 & 0.1186 \\
\hline
\end{tabular}

Like Asia and Africa, in Oceania, the number of bank branches per head is also declining. Though after 2013, the number of mobile bank outlets increased in Solomon Island and declined in Samoa. In contrast, Tonga is always on a roller coaster ride. After analyzing the access to the banking system among Oceania countries, this paper finds Solomon Island has gone through a massive change. With that change, Solomon Island is least to assure access in 2013, becomes the highest access ensuring country among selective Oceania's regional nations in 2017. For the Solomon Islands, the agent bank branch makes it possible to achieve access. After a decline from 2013 to 2015, Samoa also improves access, but Tonga faces a period of regular fluctuation with a massive dropped down after 2015. In Oceania, Tonga, scores from 0.077 in 2011 to 0.125 in 2017, performs better with continuous increases in the D3 from 2011 to 2017. Samoa also scored 0.100 remarkably in 2017. Solomon Island, the worst-performing country, assures Usages 0.059 with a relatively steep upward trend from 2016 to 2017.

\subsection{Financial Inclusion Index in Selected Developing Countries}

After calculating IFI, this study revealed that among the selected Asian countries, Bangladesh resides in a much stronger position in terms of financial inclusion. Bangladesh is exhibiting a significant improvement, from 0.05 in 2012 to 0.53 in 2017. Bangladesh and Pakistan shared nearly identical positions in 2012, but Bangladesh has gone through much development later on. Improving penetration and mobile banking outlet are the key drivers behind the growth. But still, contrasted with the global background, this may not be that big. In terms of financial inclusion, Afghanistan needs much more improvement because the IFI of 2011 is almost the same as in 2017. It is also evident that a remarkable shift among all the Asian countries has been observed after 2016. By 2017 Myanmar strengthened with a score of 0.060 on its IFI. Where Jordan has a 0.128 IFI index. All the countries show a positive trend among African countries as of 2011, reflecting an increase in financial inclusion. The African countries experienced a major shift in 2016 and witnessed a strong upward trend for IFI. Rwanda has surpassed other countries from the bottom spot in 2011 and is the top performer while counting the IFI Index at 0.65 in 2017. This development is rendered possible by improving penetration and access, specifically by increasing mobile bank account and mobile banking outlets. Uganda is lying just below Rwanda with 0.54 and Zimbabwe 0.45 .

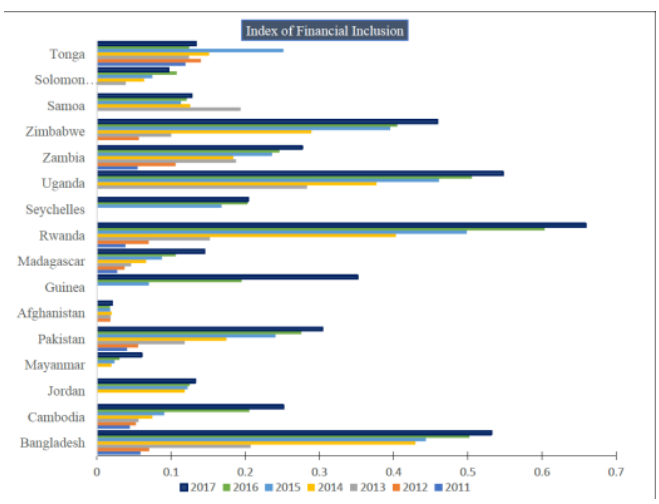

Figure 1. Comparison of index of financial inclusion (IFI) 
Though the IFI index of Tonga and Samoa is steeply rising after 2016, Solomon Islands faced a negative trend in 2017. Tonga and Samoa seem to have experienced a turbulent time before that. Except for 2017, Solomon Island meets the IFI index's continuous progress over the period covered by this paper. But the IFI index is not satisfactory for any of these countries and lies among the least financially inclusive countries. Tonga ranks top among these three nations with an index of 0.13 lower than most Asian and African countries, indicating these three countries need a lot of change in financial services to confirm financial inclusion. There are two clusters of countries for the African world, one having the IFI of more than 0.4 and another having the IFI of less than 0.4. The vital point to notice is that two African nations, Rwanda and Uganda, have the highest IFI index of all the countries mentioned in this article.

\subsection{Effects of Mobile Banking on Financial Inclusion}

This paper selects an IFI model for the study that includes the mobile banking account number and the number of mobile banking outlets as a weighted factor in penetration and access. The research attempts to examine in this portion of the review whether or not two newly introduced elements implemented in penetration and access have any effect on financial inclusion. This study calculated the IFI index of all 17 countries without integrating the mobile money account and the mobile banking outlet and compared that Index with the IFI index. The study obtained in this paper using the model discussed in equation 1 in the section on methodology. The study has integrated mobile money account as penetration component and mobile banking outlet as access component into the model.

Table 4. Comparison of IFI Index with mobile banking and without mobile banking

\begin{tabular}{llllllllll}
\hline $\begin{array}{l}\text { Country } \\
\text { Name }\end{array}$ & $\begin{array}{l}\text { D1 with } \\
\text { mobile } \\
\text { bank } \\
\text { account }\end{array}$ & $\begin{array}{l}\text { D1 } \\
\text { without } \\
\text { mobile } \\
\text { bank } \\
\text { account }\end{array}$ & $\begin{array}{l}\text { Point } \\
\text { change }\end{array}$ & $\begin{array}{l}\text { D2 with } \\
\text { mobile } \\
\text { banking } \\
\text { outlet }\end{array}$ & $\begin{array}{l}\text { D2 } \\
\text { without } \\
\text { mobile } \\
\text { banking } \\
\text { outlet }\end{array}$ & $\begin{array}{l}\text { Point } \\
\text { change }\end{array}$ & $\begin{array}{l}\text { IFI with } \\
\text { mobile } \\
\text { banking }\end{array}$ & $\begin{array}{l}\text { IFI } \\
\text { without } \\
\text { mobile } \\
\text { banking }\end{array}$ & $\begin{array}{l}\text { Point } \\
\text { change }\end{array}$ \\
\hline Rwanda & 0.239 & 0.012 & 0.227 & 2.399 & 0.008 & 2.391 & 0.659 & 0.022 & 0.637 \\
\hline Uganda & 0.205 & 0.019 & 0.186 & 1.497 & 0.005 & 1.492 & 0.548 & 0.021 & 0.527 \\
\hline Bangladesh & 0.136 & 0.045 & 0.091 & 1.407 & 0.012 & 1.395 & 0.532 & 0.061 & 0.471 \\
\hline Zimbabwe & 0.224 & 0.021 & 0.203 & 1.038 & 0.008 & 1.030 & 0.459 & 0.041 & 0.418 \\
\hline Guinea & 0.062 & 0.004 & 0.058 & 0.846 & 0.003 & 0.843 & 0.351 & 0.011 & 0.340 \\
\hline Pakistan & 0.074 & 0.021 & 0.053 & 0.676 & 0.016 & 0.661 & 0.304 & 0.033 & 0.271 \\
\hline Zambia & 0.236 & 0.010 & 0.227 & 0.500 & 0.015 & 0.485 & 0.277 & 0.021 & 0.255 \\
\hline Cambodia & 0.060 & 0.021 & 0.039 & 0.462 & 0.023 & 0.439 & 0.251 & 0.088 & 0.164 \\
\hline Madagascar & 0.084 & 0.009 & 0.075 & 0.271 & 0.004 & 0.268 & 0.145 & 0.019 & 0.126 \\
\hline Seychelles & 0.141 & 0.136 & 0.005 & 0.330 & 0.117 & 0.213 & 0.204 & 0.123 & 0.081 \\
\hline $\begin{array}{l}\text { Solomon } \\
\text { Islands }\end{array}$ & 0.074 & 0.027 & 0.047 & 0.147 & 0.016 & 0.131 & 0.097 & 0.036 & 0.061 \\
\hline Armenia & 0.150 & 0.116 & 0.034 & 0.204 & 0.088 & 0.116 & 0.152 & 0.100 & 0.052 \\
\hline Tonga & 0.177 & 0.067 & 0.111 & 0.093 & 0.054 & 0.039 & 0.134 & 0.085 & 0.049 \\
\hline Samoa & 0.182 & 0.098 & 0.083 & 0.092 & 0.070 & 0.022 & 0.127 & 0.090 & 0.037 \\
\hline Myanmar & 0.017 & 0.010 & 0.007 & 0.096 & 0.006 & 0.089 & 0.060 & 0.028 & 0.032 \\
\hline Jordan & 0.052 & 0.047 & 0.005 & 0.066 & 0.040 & 0.027 & 0.132 & 0.125 & 0.008 \\
\hline Afghanistan & 0.013 & 0.008 & 0.005 & 0.022 & 0.002 & 0.021 & 0.020 & 0.013 & 0.007 \\
\hline & & & & & & & & & \\
\hline
\end{tabular}

Table 4 shows that mobile banking plays a critical role in enhancing financial inclusion in developing countries across the globe. In column 4, the table shows that the introduction of the mobile bank account carries a positive effect on the penetration of all countries. Once again, column 7 shows the mobile banking outlets' introduction as part of access has a positive impact on all countries. Columns 8 and 9 in the table display the contrast of the countries' IFI with and 
without the mobile bank account. Column 10 presents the mobile banking outlet and disparity. Column 10 shows a significant impact on all countries because of the introduction of mobile money account and mobile banking outlet; these are potent tools for financial inclusion in the developing world.

The top IFI indexed nation is Rwanda, followed by Uganda; both have made it possible to boost financial inclusion by expanding the mobile baking market. Since the introduction of mobile banking, their Index has improved significantly from 0.02 to 0.63 and 0.52 . Bangladesh has also made a bold adjustment to the IFI index, with a move of 0.47 holds the third stand on the list. On the other side, Seychelles and Jordan were the top in IFI indexed nations without mobile banking calculation but now lie far below in the new IFI index due to lack of incorporation of effective mobile banking. It is visible from the discussion that mobile banking has a significant part in ensuring financial inclusion in emerging countries.

\section{Conclusion}

Financial services need to make sure that all the people of the globe can obtain financial facilities. Mobile banking, an influential financial inclusion tool for developing countries, allows financial institutions to reach out more easily to unbanked people than ever before. This paper considered mobile banking as a tool for financial inclusion. Because a customer can easily transfer or receive their money through mobile banking like a formal bank account. Besides, people can use mobile banking to pay for all kinds of utility and shopping bills more easily. Mobile banking provides more smooth banking penetration services to its customer. That's why this study considers the number of mobile banking account per 1000 adults as a banking penetration component. For rural and low-income people, going to a bank for small transactions is more costly than going to mobile banking outlets. Mobile banking agent outlet provides basic banking services with depositing and microloan facility. This mobile banking outlets give more people quick access to banking services. This study, for the first time, considers the number of mobile banking outlet in calculating the banking access dimension of financial inclusion index.

This paper's analysis leads to the following conclusions that mobile banking plays a crucial role in getting greater penetration, access, and usages in financial services in developing countries. From our selected Asian countries, Bangladesh is exhibiting a significant improvement in financial inclusion due to growth in mobile banking account and outlet. Bangladesh had nearly seven hundred mobile banking outlets per one lakh adults in 2017, which was only five in 2011. Pakistan had increased its mobile banking outlet from 20 to 315 per 1000 adults at the same time. Afghanistan is lagging in the Asia region due to its wartime situation and needs much more improvement in financial inclusion through the digital platform. Rwanda and Uganda have got very advancement in providing financial services through mobile banking and mobile agent outlet in Africa. Both of these countries had a higher number of mobile accounts than the traditional banking account. Trade facility with mobile banking makes these countries more engaged in financial inclusion. The IFI of our selected 17 countries has shown that a significant shift in financial inclusion is just possible through the adoption of mobile banking to provide financial services to unbanked people. Moreover, low-income people in developing countries are more accustomed to mobile banking than ATMs services of a commercial bank.

In previous mobile banking helped in getting financial access, penetration with a limited portion of usages. The contribution in mobile banking in obtaining loans and distribution of loans was relatively low in the past. In Rwanda, Uganda, Pakistan, and Bangladesh, mobile banking is now running up with a microloan facility with less documentation or no documentation. Mobile banking with the facility of trade, bill payment, receiving government, and NGO's aid will lead to financial inclusion in developing countries in a more handy way. Many developing countries also try to adopt mobile banking with more facilities. In this way, mobile banking will contribute to financial penetration, access, and usages in the future.

Apart from these, to get mobile banking services, a customer needs a mobile phone and an internet facility. If these essential two facilities are not available to unprivileged people, mobile banking is difficult. Along with mobile banking services, financial literacy is also significant for making better financial decisions. Future studies could further explore this issue by developing more innovative strategies to reach out to unbanked people who face disparities in mobile phone ownership and bandwidth allocation.

\section{References}

Aker, J. C., Boumnijel, R., McClelland, A., \& Tierney, N. (2016). Payment mechanisms and antipoverty programs: Evidence from a mobile money cash transfer experiment in Niger. Economic Development and Cultural Change, 65(1), 1-37. https://doi.org/10.1086/687578 
Akhter, N., \& Khalily, B. (2017). Impact of Mobile Financial Services on Financial Inclusion in Bangladesh. Institute for Inclusive Finance and Development (InM), Working Paper (52).

Aron, J. (2017). 'Leapfrogging': A survey of the nature and economic implications of mobile money. Retrieved from https://ideas.repec.org/p/csa/wpaper/2017-02.html

Bihari, S. C. (2011). Growth through financial inclusion in India. Journal of International Business Ethics, 4(1).

Bongomin, G. O. C., \& Ntayi, J. (2019). Trust: mediator between mobile money adoption and usage and financial inclusion. Social Responsibility Journal.

Brune, L., Giné, X., Goldberg, J., \& Yang, D. (2016). Facilitating savings for agriculture: Field experimental evidence from Malawi. Economic Development and Cultural Change, 64(2), 187-220. https://doi.org/10.1086/684014

Cámara, N., \& Tuesta, D. (2014). Measuring financial inclusion: A muldimensional index. BBVA Research Paper (14/26). https://doi.org/10.2139/ssrn.2634616

Chinoda, T., \& Kwenda, F. (2019). Do mobile phones, economic growth, bank competition and stability matter for financial inclusion in Africa? Cogent Economics \& Finance, 7(1), 1622180. https://doi.org/10.1080/23322039.2019.1622180

Della Peruta, M. (2018). Adoption of mobile money and financial inclusion: a macroeconomic approach through cluster analysis. Economics of Innovation and New Technology, 27(2), 154-173. https://doi.org/10.1080/10438599.2017.1322234

Demirguc-Kunt, A. K., \& Klapper, L. (2012). Measuring financial inclusion: The global findex database. The World Bank. https://doi.org/10.1596/1813-9450-6025

Demirguc-Kunt, A. K., Leora Dorothe, S., Saniya, A., \& Jake, H. (2018). Global Findex Database 2017: Measuring financial inclusion and the fintech revolution. Washington, DC: World Bank, CC BY 3.0 IGO. https://doi.org/10.1596/978-1-4648-1259-0

Dev, S. M. (2006). Financial inclusion: Issues and challenges. Economic and Political Weekly, 4310-4313.

Evans, O. (2018). Connecting the poor: the internet, mobile phones and financial inclusion in Africa. Digital Policy, Regulation and Governance, 20(6), 568-581. https://doi.org/10.1108/DPRG-04-2018-0018

Foster, C., \& Heeks, R. (2013). Conceptualising inclusive innovation: Modifying systems of innovation frameworks to understand diffusion of new technology to low-income consumers. The European Journal of Development Research, 25(3), 333-355. https://doi.org/10.1057/ejdr.2013.7

Garg, S., \& Agarwal, P. (2014). Financial inclusion in India-a Review of initiatives and achievements. IOSR Journal of Business and Management, 16(6), 52-61. https://doi.org/10.9790/487X-16615261

Gupte, R., Venkataramani, B., \& Gupta, D. (2012). Computation of financial inclusion index for India. Procedia-Social and Behavioral Sciences, 37, 133-149. https://doi.org/10.1016/j.sbspro.2012.03.281

Jack, W., \& Suri, T. (2014). Risk sharing and transactions costs: Evidence from Kenya's mobile money revolution. American Economic Review, 104(1), 183-223. https://doi.org/10.1257/aer.104.1.183

Kim, J.-H. (2016). A study on the effect of financial inclusion on the relationship between income inequality and economic growth. Emerging Markets Finance and Trade, 52(2), 498-512. https://doi.org/10.1080/1540496X.2016.1110467

Lashitew, A. A., Van Tulder, R., \& Liasse, Y. (2019). Mobile phones for financial inclusion: What explains the diffusion of mobile money innovations?. Research Policy, 48(5), 1201-1215. https://doi.org/10.1016/j.respol.2018.12.010

Mas, I., \& Radcliffe, D. (2011). Scaling mobile money. Journal of Payments Strategy \& Systems, 5(3), 298-315.

Maurer, B. (2012). Mobile Money: Communication, Consumption and Change in the Payments Space. The Journal of Development Studies, 48(5), 589-604. https://doi.org/10.1080/00220388.2011.621944

Mbiti, I., \& Weil, D. N. (2013). The home economics of e-money: velocity, cash management, and discount rates of M-Pesa users. American Economic Review, 103(3), 369-374. https://doi.org/10.1257/aer.103.3.369

McKinnon, R. I. (1973). Money and capital in economic development. Washington: Brookings Institute. 
Mishra, V., \& Bisht, S. S. (2013). Mobile banking in a developing economy: A customer-centric model for policy formulation. Telecommunications Policy, 37(6-7), 503-514. https://doi.org/10.1016/j.telpol.2012.10.004

Munyegera, G. K., \& Matsumoto, T. (2016). Mobile money, remittances, and household welfare: Panel evidence from rural Uganda. World Development, 79, 127-137. https://doi.org/10.1016/j.worlddev.2015.11.006

Neaime, S., \& Gaysset, I. (2018). Financial inclusion and stability in MENA: Evidence from poverty and inequality. Finance Research Letters, 24, 230-237. https://doi.org/10.1016/j.frl.2017.09.007

Ouma, S. A., Odongo, T. M., \& Were, M. (2017). Mobile financial services and financial inclusion: Is it a boon for savings mobilization?. Review of Development Finance, 7(1), 29-35. https://doi.org/10.1016/j.rdf.2017.01.001

Rangarajan, C. (2008). Report of the committee on financial inclusion. Ministry of Finance, Government of India.

Rizvi, S. K. A., Naqvi, B., \& Tanveer, F. (2017). Mobile banking: A potential catalyst for financial inclusion and growth in Pakistan.

Roller, L.-H., \& Waverman, L. (2001). Telecommunications infrastructure and economic development: A simultaneous approach. American Economic Review, 91(4), 909-923. https://doi.org/10.1257/aer.91.4.909

Sameer, K., Chandrashekhar, R., Chakrabarty, K., \& Phatak Deepak, B. (2009). Financial Inclusion. Academic Foundation.

Sarma, M. (2008). Index of financial inclusion.

Sarma, M. (2012). Index of Financial Inclusion-A measure of financial sector inclusiveness.

Sarma, M., \& Pais, J. (2008). Financial inclusion and development: A cross country analysis. New Delhi: Madras Schools of Economics.

Sharma, D. (2016). Nexus between financial inclusion and economic growth: Evidence from the emerging Indian economy. Journal of Financial Economic Policy, 8(1), 13-36. https://doi.org/10.1108/JFEP-01-2015-0004

Turegano, D. M., \& Herrero, A. G. (2018). Financial inclusion, rather than size, is the key to tackling income inequality. The Singapore Economic Review, 63(1), 167-184. https://doi.org/10.1142/S0217590818410047

United Nations. (2006). Building inclusive financial sectors for development. United Nations Capital Development Fund.

Waverman, L., Meschi, M., \& Fuss, M. (2005). The impact of telecoms on economic growth in developing countries. The Vodafone Policy Paper Series, 2(3), 10-24.

\section{Copyrights}

Copyright for this article is retained by the author(s), with first publication rights granted to the journal.

This is an open-access article distributed under the terms and conditions of the Creative Commons Attribution license (http://creativecommons.org/licenses/by/4.0/). 